\title{
Update: Predatory Open-Access Scholarly Publishers
}

doi:10.5260/chara.12.1.50

By Jeffrey Beall (Auraria Library, University of Colorado, Denver)

<jeffrey.beall@ucdenver.edu>

View Jeffrey's blog at <http://metadata.posterous.com/>.

$\mathrm{T}$ he number of predatory, Open-Access publishers keeps growing. I researched my April 2010 review for The Charleston Advisor (Vol.11, no. 4) on "Predatory Open Access Scholarly Publishers" in January and February 2010. Since then, two people have informed me about two additional predatory publishers they discovered and I have also come across a new one.

The first publisher, Medwell Journals <http://www.medwelljournals. com/home.php $>$, appears to be a brand from the Faisalabad, Pakistanbased firm Science Alert <http://scialert.net>. This firm already has several brands, including several that I included in my review (e.g., Academic Journals, Inc., and ANSINetwork), and it appears it is trying to saturate the market with multiple brands. Thanks to Nancy Hunter at Colorado State University for alerting me to this new site.

Medwell hosts 35 online journals. The journals all bear broad and generic titles and include The Surgery Journal, The Cardiology [sic], and The Social Sciences. The lineup also includes Botany Research Journal and Plant Sciences Research. Aren't botany and plant science the same thing?

The second one is International Research Journals <http://www.interesjournals.org/index.htm>, and according to Dr. Mangesh Thorat, who alerted me to its existence, this publisher appears to be a spinoff of one of the publishers I reviewed in my original article, namely Academic Journals, Inc. < http://www.academicjournals.org/>. This publisher is based in Nigeria, I think, based on some information found on their Contact Us page. Most predatory publishers hide or misrepresent their headquarters location information.

International Research Journals publishes ten e-serials and is among the most entertaining of these bogus publishers because of the bizarre pictures they use on their products. Follow the links to see the images! The banner at the top of their home page is one of the least professional-looking I've ever seen <http://www.interesjournals.org/ index.htm>. It includes a badly cropped photo of a duckling swimming in a dirty pond, and because the photo isn't wide enough to fit the page, they duplicated it to make it fit. Their cover images are even more hilarious. A recent cover from the International Research Journal of Biotechnology <http://www.interesjournals.org/IRJOB/index. $\mathrm{htm}>$ looks like a picture of a salad covered by some type of meat or cheese loaf. Who in their right mind would submit a paper to this journal? Even more curious is the cover of the Journal of Medicine and Medical Sciences from the same publisher. Perhaps he expects to increase its page view meter with images that would attract interest; see <http://www.interesjournals.org/JMMS/Contents/2010\%20 content/May.htm $>$. There's not a single article in the issue that deals with the topics suggested by the cover. This journal's coverage is extremely broad: "Medicine and medical sciences," That's about as unfocused as you can get, and this broad coverage is typical among predatory publishers - they want to accept as many papers as they can and take the author fees that come along with them. Thank you to Dr. Morat for alerting me to this publisher.
Finally, I recently discovered OMICS Publishing Group <http://omicsonline.org/index.php>, which appears to be a brand-new entry into the predatory Open-Access publishing industry, an industry that seems to be growing by the week. Based on the international dialing code on OMICS' Contact page, it appears that this publisher is based in India (the site does not give an address or location, only telephone numbers, including some in the U.S. area code 650). OMICS offers 68 peer-reviewed journals, most of which are health sciences titles. Few of the journals have any content. When one clicks on Current Issue or Previous issue on each journal's home page, a page appears that says "coming soon."

Having a large number of titles, as does the OMICS Publishing Group, is typical of predatory Open-Access publishers. Also typical is each journal's broad coverage. For instance, among this publisher's titles we find Earth Science and Climate Change, Anesthesia and Clinical Research, and Bacteriology and Parasitology. By offering 68 titles each with a broad coverage, this publisher is tacitly saying it will publish anything.

OMICS' Web site stands out for its sophisticated look and feel. It has a very professional look and repeatedly pays homage to the Open Access movement, a movement it is exploiting. The tag line on the publisher's home page reads "OMICS Publishing Group: An Open Access publisher for the advancement of science and technology." OMICS very cleverly uses logos from several legitimate organizations associated with Open Access on its pages. For example, on its home page, the publisher has logos for CrossRef, PubMed Central, DOAJ, Index Copernicus, and Scientific Commons.

The publisher also has a link called Conferences that leads to a page with scientific conference information, a trick to make the site look more scholarly and legitimate. The home page uses graphics and layout that effectively mimic legitimate publishers' Web sites. OMICS uses the "author-pays" model (OA gold) to support Open Access. Buried on one page I found a reference to "handling fees" that are charged upon acceptance of a manuscript.

The predatory Open Access publishing industry is getting more and more competitive. This publisher's marketing strategy is to make its site appear just like the sites of legitimate publishers, a strategy it accomplishes quite well, for the site is slick and convincing. I never was able to determine exactly what OMICS stands for or means; the name is not explained. Perhaps it is a play on the "omics" suffix found in the names of fields of study such as genomics and proteomics.

\section{About the Author}

Jeffrey Beall is Metadata Librarian at Auraria Library, University of Colorado, Denver. He earned his M.S.L.S. degree from the University of North Carolina at Chapel Hill, and he also holds an M.A. in English from Oklahoma State University. He has worked as an academic librarian for 19 years. His research and articles have been published in numerous journals including American Libraries, College and Research Libraries, and Cataloging and Classification Quarterly. 